\title{
THE THERMAL HISTORY OF THE LHASA BLOCK, SOUTH TIBETAN PLATEAU BASED ON FTD AND AR-AR DATING
}

\author{
T. F. YANG*, J. R. WANG*, C. H. LO*, S. L. CHUNG*, R. L. TIEN*, R. XU ** \\ AND W. DENG ** \\ * Dept. Geology, National Taiwan University, 245 Choushan Road, Taipei 106-17, Taiwan \\ ** Inst. Geology, Chinese Academy of Sciences, P.O. Box 9625, Beijing 100029, China
}

\begin{abstract}
Twelve basement samples were collected from South Tibet Plateau for FTD and Ar-Ar analysis to demonstrate their uplifting history since Cenozoic era. The preliminary results from different minerals with different closure temperatures, including apatite and zircon for fission-track dating, and $\mathrm{K}$-feldspar, biotite for $\mathrm{Ar}$-Ar dating, show that at least four stages of thermal history can be recognized in the studied area.
\end{abstract}

\section{KEYWORDS}

Tibetan Plateau; Lhasa Block; thermal history; fission-track dating; Ar-Ar dating.

\section{INTRODUCTION}

The Tibet Plateau, which is bound by the Jinsha Suture in the North and the Indus Zangbo Suture in the South (Fig. 1A), is regarded as the result of the northward convergence of India into Asia over the past 40 to $50 \mathrm{Ma}$. Many thermochronologic studies show that rapid uplift and unroofing of southern Tibet began about 20 million years ago and the present elevation of much of the Tibetan plateau was attained by about 8 million years ago (e.g., Harrison et al., 1992; Pan et al., 1993; Coleman and Hodge, 1995; Copeland et al., 1995). Although many models have been proposed to account for its thickened crust and high elevation, the uplift of the Tibetan plateau may be the consequence of the convective removal of the lower portion of the thickened Asian lithosphere (e.g., Platt and England, 1994). Furthermore, Chung et al. (1998) argued that there were diachronous uplift events starting $40 \mathrm{Myr}$ ago based on the observation of alkaline magmatic rocks in eastern and western Tibet. Using the fissiontrack dating (FTD) and Ar-Ar dating technique, we will examine the thermal history of southern Tibet by dating its basement rocks directly in this study.

\section{ANALYSIS AND RESULTS}

Representative samples were collected from Lhasa Block of South Tibet and the northern part of the Lhasa Block. Seven samples are from the Gangdese Bothlith (Fig. 1C), meanwhile, the others are from the northern part of the Lhasa Block (Fig. lB). For comparison, one granodiorite sample (K) was also collected near the Jinsha Suture (Fig. 1A).

\section{Fission-track dating result}

Enough zircon and apatite grains separated from the samples were mounted in teflon and epoxy respectively for irradiation. "Grain-by-grain" and mica external detector techniques were adopted to obtain individual grain ages. A zeta value (e.g., Green, 1985) of $27.9 \pm 1.5(1 \sigma)$ has been obtained for zircons of Fish Canyon Tuff (Yang et al., 1995). The pooled age used in this study is calculated by pooling counts for the counted grains (Tagami et al., 1988). Statistical errors were calculated from 
the Poisson uncertainties in fossil and induced tracks, and in counts used to determine the neutron dose as well (Green, 1981). The detailed analytical procedures are those reported in Yang et al. (1995).

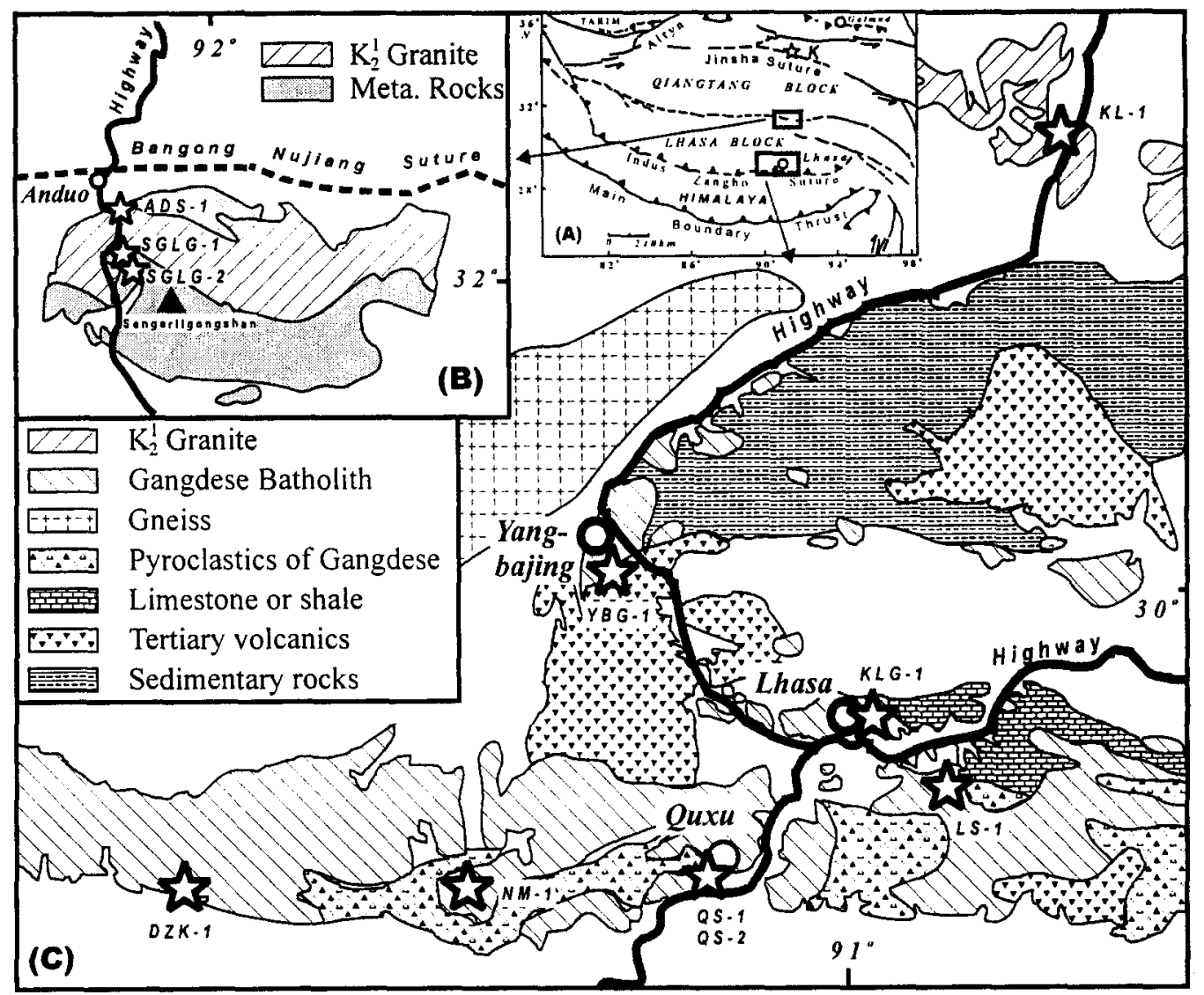

Fig. 1. Sample localities in this study. (A) Simplified tectonic setting of Tibetan plateau; open star (K) is the location of sample HSS-1; (B) Sample localities and geologic map of North Lhasa Block; and South Lhasa Block $(\mathrm{C})$.

Table 1 shows the fission-track dating results of this study and indicate a wide age range of ages $(16.7 \sim 63.4 \mathrm{Ma})$ with small errors $(3.2-8.6 \%)$. Except for the apatite date for sample NM-1, all data are consistent with their peak age and $\chi^{2}$ age within one standard deviation error and exhibit a symmetric distribution in the composite probability density plot. This implies that the data have ideally recorded the last thermal event. As expected, all the zircon dates are significantly older than the apatite data from the same samples.

\section{Ar-Ar dating}

Samples were wrapped in aluminum foil packets and irradiated for 8 hours in the THOR nuclear reactor at Tsing-Hua University, Taiwan. The maximum flux gradient was less than $0.9 \%$ within overall sample volume. The irradiated samples were step-heated using a Lindberg resistance furnace and analyzed by a Varian-MAT GD150 mass spectrometer at the National Taiwan University. The monitor standard was the LP-6 biotite $(127.7 \pm 1.4 \mathrm{Ma})$ and ages were calculated using the constants recommended by Steiger and Jäger (1977). All errors are quoted at the $1 \sigma$ level and do not include the uncertainty of the monitor age. Experimental details are given in Lo and Lee (1994).

The Ar-Ar dating results obtained in this study is shown in Table 2. All samples exhibit plateau spectra and are consistent with the inverse isochron ages (e.g., Fig. 2), although some abnormal high values of $\left({ }^{40} \mathrm{Ar}{ }^{36} \mathrm{Ar}\right)_{0}$ are obtained due to the narrow range data set of argon isotopic ratios (e.g., Fig. 
2A). The Ar-Ar ages show a wide age spectrum of 49.1 196.0 Ma and can be divided into three groups: (1) 200Ma, (2) 140 160Ma, and (3) 50 60 Ma respectively. They are much older than the fission-track ages.

Table 1. The Fission-track dating result of representative basement rocks from Tibetan Plateau.

\begin{tabular}{cccccccccc}
\hline \multirow{2}{*}{ Sample } & Locality & $G$ & Min. & \multicolumn{2}{c}{ Density of tracks $\left(10^{6} / \mathrm{cm}^{2}\right)$} & $\begin{array}{c}\text { Pooled age } \\
(\mathrm{Ma} \pm 1 \sigma)\end{array}$ & $\begin{array}{c}\chi^{2} \text { age } \\
(\mathrm{Ma} \pm 1 \sigma)\end{array}$ & $\begin{array}{c}\text { Peak } \\
\text { age }\end{array}$ \\
\hline HSS-1 & Kokshili & 12 & $\mathrm{Ap}$ & $1.6(241)$ & $13.1(937)$ & $1.55(2038)$ & $63.4 \pm 4.6$ & $63.4 \pm 4.6$ & 63.1 \\
ADS-1 & Anduo & 16 & $\mathrm{Ap}$ & $1.8(414)$ & $14.2(1609)$ & $0.97(2000)$ & $39.8 \pm 2.2$ & $39.8 \pm 2.2$ & 39.2 \\
SGLG-1 & Sengerli- & 31 & $\mathrm{Zr}$ & $7.8(3759)$ & $7.1(110)$ & $1.82(2021)$ & $56.3 \pm 1.8$ & $54.1 \pm 2.0$ & 56.3 \\
& gongshan & 16 & $\mathrm{Ap}$ & $1.0(219)$ & $8.5(48)$ & $0.97(2000)$ & $34.8 \pm 2.6$ & $33.1 \pm 2.8$ & 34.0 \\
KL-1 & Gulu & 18 & $\mathrm{Zr}$ & $5.4(1145)$ & $9.6(2029)$ & $3.47(2103)$ & $54.8 \pm 2.3$ & $52.7 \pm 2.6$ & 54.0 \\
& & 18 & $\mathrm{Ap}$ & $1.8(362)$ & $23.2(2458)$ & $1.55(2038)$ & $37.8 \pm 2.2$ & $35.8 \pm 2.3$ & 35.5 \\
YBG-1 & Yang- & 18 & $\mathrm{Zr}$ & $3.4(827)$ & $8.9(2178)$ & $3.47(2103)$ & $36.9 \pm 1.7$ & $35.6 \pm 1.8$ & 35.9 \\
& bajing & 11 & $\mathrm{Ap}$ & $1.5(169)$ & $44.7(2405)$ & $1.55(2038)$ & $17.3 \pm 1.4$ & $17.3 \pm 1.4$ & 16.9 \\
KLG-1 & Lhasa & 14 & $\mathrm{Zr}$ & $4.2(920)$ & $4.0(883)$ & $1.82(2021)$ & $53.1 \pm 2.8$ & $51.2 \pm 3.0$ & 52.8 \\
& & 14 & $\mathrm{Ap}$ & $1.2(162)$ & $15.1(73)$ & $0.97(2000)$ & $24.4 \pm 2.1$ & $22.2 \pm 2.3$ & 23.4 \\
LS-1 & Dagze & 30 & $\mathrm{Zr}$ & $7.8(4343)$ & $7.0(3887)$ & $1.82(2021)$ & $57.0 \pm 1.8$ & $55.8 \pm 1.8$ & 56.9 \\
& & 18 & $\mathrm{Ap}$ & $1.6(354)$ & $16.8(102)$ & $0.97(2000)$ & $29.6 \pm 1.8$ & $26.5 \pm 2.1$ & 29.6 \\
QS-1 & Quxu & 24 & $\mathrm{Zr}$ & $5.4(3020)$ & $6.1(296)$ & $1.82(2021)$ & $43.8 \pm 1.5$ & $40.3 \pm 1.8$ & 42.9 \\
& & 17 & $\mathrm{Ap}$ & $1.3(302)$ & $18.5(2082)$ & $0.97(2000)$ & $20.2 \pm 1.4$ & $19.2 \pm 1.6$ & 19.8 \\
QS-2 & Quxu & 14 & $\mathrm{Zr}$ & $3.1(598)$ & $7.8(1486)$ & $3.47(2103)$ & $38.2 \pm 2.1$ & $36.5 \pm 2.3$ & 38.9 \\
& & 16 & $\mathrm{Ap}$ & $1.5(273)$ & $40.4(3702)$ & $1.55(2038)$ & $18.2 \pm 1.1$ & $17.6 \pm 1.3$ & 17.9 \\
NM-1 & Neymu & 33 & $\mathrm{Zr}$ & $2.9(1391)$ & $3.3(1594)$ & $1.82(2021)$ & $44.5 \pm 1.9$ & $42.0 \pm 2.1$ & 44.2 \\
& & 21 & $\mathrm{Ap}$ & $1.5(320)$ & $26.6(138)$ & $0.97(2000)$ & $16.7 \pm 1.0$ & $13.2 \pm 1.2$ & 14.2 \\
DZK-1 & Dazuka & 16 & $\mathrm{Zr}$ & $4.5(1017)$ & $9.1(2043)$ & $3.47(2103)$ & $48.4 \pm 2.1$ & $48.3 \pm 2.2$ & 48.1 \\
& & 14 & $\mathrm{Ap}$ & $2.0(315)$ & $29.9(2337)$ & $1.55(2038)$ & $32.6 \pm 2.0$ & $31.7 \pm 2.1$ & 32.0 \\
\hline
\end{tabular}

External detector grain-by-grain method was used in this study. $G$ is the number of counted grains; $N$ is the number of counted tracks. $\chi^{2}$ age is the pooled age, which passed the $\chi^{2}$ test at $5 \%$ level. Peak age $(\mathrm{Ma})$ is the highest peak of the composite probability density plot of all grain dates in one sample. $\mathrm{Ap}=$ apatite; $\mathrm{Zr}=$ zircon.

Table 2. The Ar-Ar dating result of representative basement rocks from Tibetan Plateau.

\begin{tabular}{ccccccccc}
\hline Sample & Location & $\begin{array}{c}\text { Rock } \\
\text { type }\end{array}$ & $\begin{array}{c}\text { Mineral } \\
\text { dated }\end{array}$ & $\begin{array}{c}\text { Plateau age } \\
(\mathrm{Ma} \pm 1 \sigma)\end{array}$ & $\begin{array}{c}\text { Isochron age } \\
(\mathrm{Ma} \pm 1 \sigma)\end{array}$ & $\begin{array}{c}\left({ }^{40} \mathrm{Ar} /{ }^{36} \mathrm{Ar}\right) \\
( \pm 1 \sigma)\end{array}$ & MSWD & $N$ \\
\hline HSS-1 & Kokshili & GD & Biotite & $196.0 \pm 1.9$ & $192.7 \pm 2.2$ & $626.8 \pm 162.4^{*}$ & 2.4 & 11 \\
ADS-1 & Anduo & GD & Biotite & $157.6 \pm 1.6$ & $147.0 \pm 2.3$ & $1120 \pm 475^{*}$ & 2.7 & 12 \\
& & & K-feldspar & $141.6 \pm 1.4$ & $143.3 \pm 1.6$ & $273.6 \pm 19.1$ & 6.7 & 7 \\
SGLG-1 & Sengligon- & S & Biotite & $142.1 \pm 0.1$ & $142.1 \pm 2.0$ & $294.5 \pm 7.6$ & 1.1 & 9 \\
SGLG-2 & shan & S & Biotite & $147.8 \pm 1.5$ & $140.8 \pm 3.9$ & $1217 \pm 373 *$ & 1.9 & 11 \\
KLG-1 & Lhasa & SY & Biotite & $55.8 \pm 0.6$ & $55.7 \pm 0.7$ & $297.6 \pm 3.3$ & 4.2 & 12 \\
LS-1 & Dagze & GD & Biotite & $61.1 \pm 0.6$ & $61.0 \pm 0.7$ & $304.0 \pm 13.6$ & 2.0 & 10 \\
NM-1 & Nyemu & GD & Biotite & $49.1 \pm 0.5$ & $49.4 \pm 0.5$ & $304.6 \pm 20.9$ & 3.2 & 9 \\
\hline
\end{tabular}

Rock type of $\mathrm{GD}=$ granodiorite; $\mathrm{S}=$ schist; $\mathrm{SY}=$ syenite. $\quad\left({ }^{40} \mathrm{Ar} /{ }^{36} \mathrm{Ar}\right)_{0}$ is the ratio at intercept, MSWD is the mean squared weighted deviate and $N$ is the number of steps used in the age calculation.

* The abnormally high value of $\left({ }^{40} \mathrm{Ar} r^{36} \mathrm{Ar}\right)_{\mathrm{o}}$ is not due to the inherited argon, but is due to the difficulty to extrapolate the intercept value from the narrow range of the data set (see Fig. 2A). 

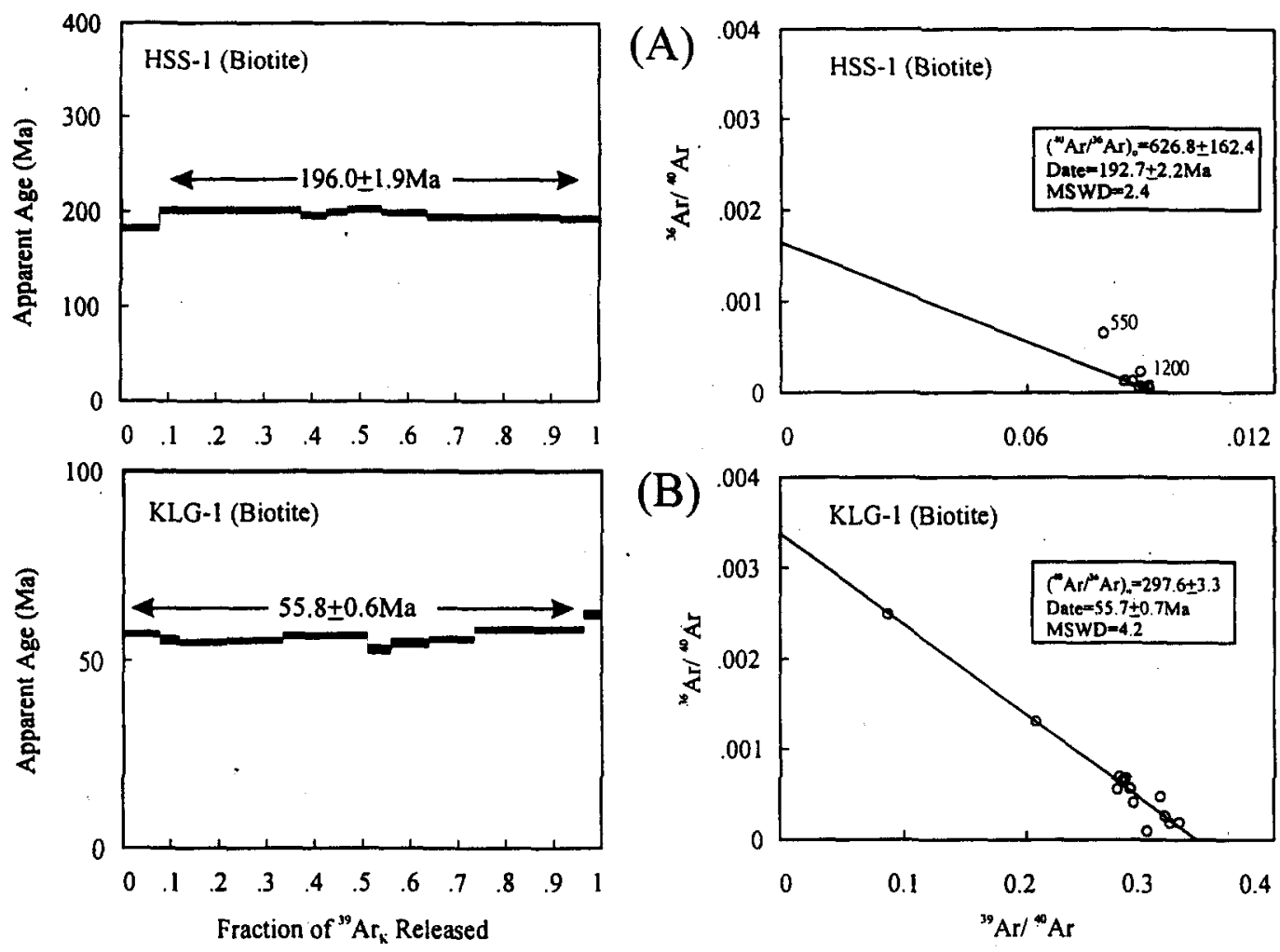

Fig. 2. Representative age spectrum of Ar-Ar date (left side) and the isochron plot (right side): The plateau age of the age spectrum is consistent with inverse isochron age (see also Table 2). The abnormally high $\left({ }^{40} \mathrm{Ar} /{ }^{36} \mathrm{Ar}\right)$, value of sample is due to the narrow range of isotopic ratios (A); however, those samples with wide isotopic ratios can easily extrapolate the intercept of $\left({ }^{40} \mathrm{Ar} /{ }^{36} \mathrm{Ar}\right)_{0}$ and obtain the value close to air ratio (B).

\section{DISCUSSION}

\section{Thermal history of the studied area}

The closure temperature of dated mineral is believed related to the cooling rate, heating time, and the composition of the mineral (e.g., James and Durrani, 1986; Yamada et al., 1995). Sorkhabi (1993) discussed the time-temperature pathways of Himalayan and Trans-Himalayan crystalline rocks using different closure temperatures for different range of apatite FT dates. Wagner and Van de Haute (1992) suggested the track-retention temperatures for zircon is $210 \pm 40^{\circ} \mathrm{C}$, and $100 \pm 20^{\circ} \mathrm{C}$ for apatite. According to the composition, we can derive the closure temperature of $350 \pm 50^{\circ} \mathrm{C}$ for biotite and $280 \pm 25^{\circ} \mathrm{C}$ for $\mathrm{K}$-feldspar Ar-Ar dates. We will adopt above temperatures in latter discussion. Combining the results of this study, Fig. 3 summarizes the results of our study regarding the thermal history of the Lhasa Block. At least four stages of cooling can be identified in the studied area.

The first stage is $>60 \mathrm{Ma}$ : this stage has only been recorded in the dated minerals from North Lhasa and Tibet. Interestingly, there is one $63.4 \mathrm{Ma}$ of apatite FT date from North Tibet near the Jinsha Suture. Because of the low track stability in apatite, it implies that the Jinsha Suture has been relative stable after $60 \mathrm{Ma}$ even during the time of severe collision. The estimated cooling rate is rather low ca. $\angle 2^{\circ} \mathrm{C} / \mathrm{m}$.y. during this period.

The second stage is about $60 \sim 40 \mathrm{Ma}$ : Both south and north of the Lhasa Block, the basement rocks have recorded this stage. However, the cooling rate recorded in South Lhasa Block is much higher $\left(43.7 \sim 20.9^{\circ} \mathrm{C} / \mathrm{m} . \mathrm{y}\right.$.) than in the North $\left(5.2^{\circ} \mathrm{C} / \mathrm{m} . \mathrm{y}\right.$. $)$. Such a high cooling rate obviously is related to 
the severe collision of India and Asia. However, this fast cooling (unroofing) event seems not to be clearly recorded in the basement rocks of North Lhasa Block/Tibet.
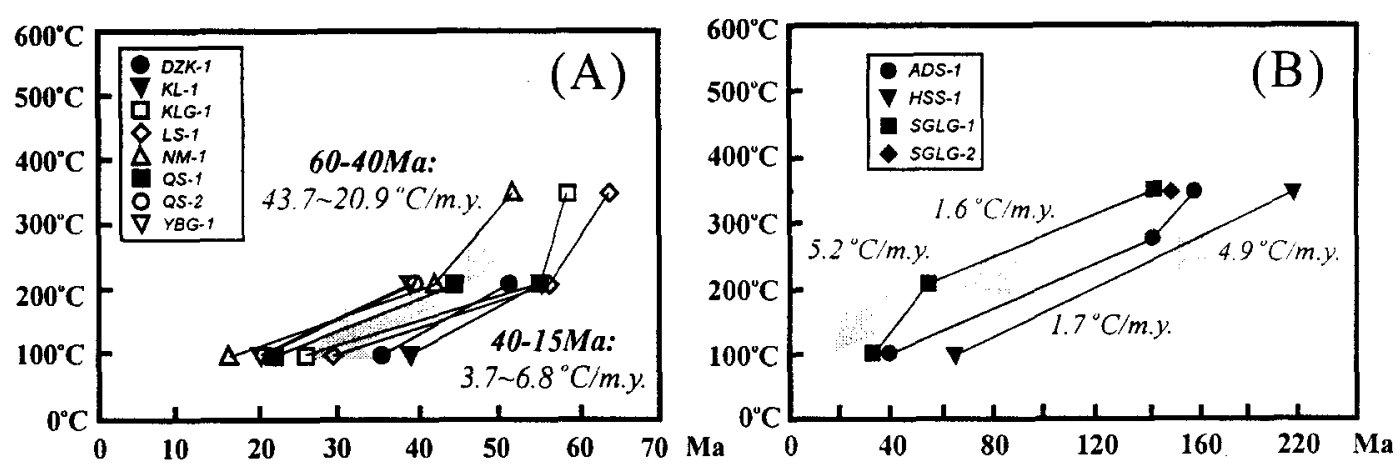

Fig. 3. The thermal history of the Gangdese batholith of the Lhasa Block, S. Tibet (A); and North of Lhasa Block and Tibet (B).

The third stage occurs in the period of $40 \sim 15 \mathrm{Ma}$ : The cooling rate is relative low $\left(3.7 \sim 6.8^{\circ} \mathrm{C} / \mathrm{m} . \mathrm{y}\right.$.) during this period. It is worth to note that no thermal event has been recorded after $35 \mathrm{Ma}$ in the Northern Tibet Plateau in this study. This implies that North Tibet may have reached its ultimate altitude and no significant thermal events occurred to affect this area.

The last stage is younger than $15 \mathrm{Ma}$ : There is a consensus that the South Tibetan plateau may have started its fast uplift since $20 \mathrm{Ma}$, and might have reached its ultimate altitude ca. $8 \mathrm{Ma}$ (e.g., Harrison et al., 1992; Coleman and Hodges, 1995). Furthermore, based on apatite fission track thermochronology Pan et al. (1993) reported that there was a pulse of rapid cooling $\left(>80^{\circ} \mathrm{C} / \mathrm{m} . \mathrm{y}\right.$.) around 20 15 Ma in the Quxu area, southern Lhasa terrane. Although we do have obtained records of less than $20 \mathrm{Ma}$ in this study, nevertheless, there are not enough data to show the rapid cooling event after $20 \mathrm{Ma}$. It is necessary to collect more samples from different altitudes and apply some other dating technique with lower blocking temperatures. For instances, U-Th-He dating of apatite with a closure temperature possibly as low as $75 \pm 5^{\circ} \mathrm{C}$ (Wolf et al., 1997) might be a potential method for the purpose of resolving the detailed cooling history in this area after $20 \mathrm{Ma}$.

\section{Diachronous uplift of Tibet}

In addition to the generally accepted fast uplift of the Tibetan plateau which started from $20 \mathrm{Myr}$ ago, Chung et al. (1998) suggested that the fast uplift of Tibet commenced much earlier since $40 \mathrm{Myr}$ ago. For lack of the samples from eastern Tibet, we cannot examine if fast uplift in sastern Tibet occurred much earlier than in western Tibet (Chung et al., 1998). However, we can conclude that at least two diachronous uplift events have occurred in Tibet and the first fast thermal cooling (uplift) event occurred at $60 \sim 40 \mathrm{Ma}$. This fast uplift is believed related to the collision event between Indian and Asian. All our collected samples have obtained the thermal event record of this period. This implies that the effect of this event may have been recorded in the entire Tibetan plateau, not only in eastern Tibet. Subsequently, the collision was ongoing, however, only in the southern part of Tibet the second fast uplift event has been recorded $(<20 \mathrm{Ma})$.

\section{CONCLUSION}

According to the results of our study, at least four stages of cooling in the Lhasa Block of South Tibet can be recognized. Stage I ( $>60 \mathrm{Ma}$ ): In the northern part of the studied area, some pre- $60 \mathrm{Ma}$ thermal events have been recorded and not been reset by the later collision event. It implies that there were some other event occurred before $60 \mathrm{Ma}$ in this area. Stage II (60 40 Ma): A rather fast cooling rate of $20.9 \sim 43.7^{\circ} \mathrm{C} / \mathrm{m} . \mathrm{y}$. is calculated for the $60 \sim 40$ Ma period. The fast cooling may reflect fast unroofing in this area due to the collision between Indian Plate and Eurasian Plate. Stage III (40 15 $\mathrm{Ma})$ : Subsequently, a relatively slow cooling rate $\left(3.7 \sim 6.9^{\circ} \mathrm{C} / \mathrm{m} . \mathrm{y}\right.$.) is considered to result from a slow- 
down of unroofing. No obvious tectonic event has been recorded to cause the significant unroofing during the period. Stage IV $(<20 \mathrm{Ma})$ : Some ages have been dated in S. Lhasa samples. Nevertheless, none of sample from northern part of Lhasa Block can obtain this event record in this study. It suggests that the general accepted rapid uplifting event after $20 \mathrm{Ma}$ may only occur in South of Tibetan Plateau.

Acknowledgment - The authors wish to thank Drs. W. Lo and X. Li for helping in sample collection and mineral separation. Valuable comments and discussions provided by Drs. Olesch M., Van de haute P., Knittel U. and two anonymous reviewers were helpful to improve the manuscript. This study was financial supported by the National Science Council, Taiwan, ROC (NSC87-2116-M-002-018; NSC88-2116-M-002-029).

\section{REFERENCES}

Chung S.L., Lo C.H., Lee T.Y., Zhang Y., Xie Y., Li X., Wang K.L. and Wang P.L. (1998) Diachronous uplift of the Tibetan plateau starting from $40 \mathrm{Myr}$ ago. Nature 394, 723-725.

Coleman M. and Hodges K. (1995) Evidence for Tibetan plateau uplift before 14 Myr ago from a new minimum age for east-west extension. Nature 374, 49-52.

Copeland P., Harrison T.M., Kidd W. S. F., Xu R. and Zhang Y. (1995) Thermal evolution of the Gangdese batholith, southern Tibet: A history of episodic unroofing. Tectonics 14, 223-236.

Green P.F. (1981) A new look at statistics in fission-track dating. Nucl. Tracks 5, 77-86.

Green P.F. (1985) Comparison of zeta calibration baselines or fission-track dating of apatite, zircon and sphene. Chem. Geol. 58, 1-22.

Harrison T.M., Copeland P., Kidd W.S.F. and Yin A. (1992) Raising Tibet. Science 255, 1663-1670.

James K. and Durrani S.A. (1986) The effect of crystal composition on fission-track annealing and closure temperature in geological minerals: implications for the cooling rates of the terrestrial and extraterrestrial rocks. Nucl. Tracks Radiat. Meas. 11, 277-282.

Lo C.H. and Lee C.Y. (1994) ${ }^{40} \mathrm{Ar} /{ }^{39} \mathrm{Ar}$ method of $\mathrm{K}$-Ar age determination of geological samples using Tsing-Hua Open-pool (THOR) Reactor. Jour. Geol. Soc. China 37, 143-164.

Pan Y., Copeland P., Roden M.K., Kidd W.S.F. and Harrison T.M. (1993) Thermal and unroofing history of the Lhasa area, southern Tibet-evidence from apatite fission track thermochronology. Nucl. Tracks Radiat. Meas. 21, 543-554.

Platt J.P. and England P.C. (1994) Convective removal of lithosphere beneath mountain belts: thermal and mechanical consequences. Am. J. Sci. 294, 307-336.

Sorkhabi R.B. (1993) Time-temperature pathways of Himalayan and Trans-Himalayan crystalline rocks: a comparison of fission-track ages. Nucl. Tracks Radiat. Meas. 21, 535-542.

Steiger R.H. and Jäger E. (1977) Submission on geochronology: convention on the use of decay constants in geo- and cosmochronology. Earth Planet. Sci. Lett. 36, 359-362.

Tagami T., Lal N., Sorkhabi R.B., Ito H. and Nishimura S. (1988) Fission track dating using external detector method: a laboratory procedure. Mem. Faculty Sci. Kyoto Univ. Ser. Geol. Mineral LIII, $1-30$.

Wagner G and Van den haute P. (1992) Fission-track dating. Kluwer Academic Publishers, Dordrecht, Netherlands.

Wolf R.A., Farley K.A. and Silver L.T. (1997) Assessment of (U-Th)/He thermochronometry: the lowtemperature history of the San Jacinto moutains, California. Geology 25, 65-68.

Yamada R., Tagami T., Nishimura S and Ito H. (1995) Annealing kinetics of fission tracks in zircon: an experimental study. Chem. Geol. 122, 249-258.

Yang T.F., Tien J.L., Chen C.-H., Lee T. and Punongbayan R.S. (1995) Fission-track dating of volcanics in the northern part of the Taiwan-Luzon Arc: eruption ages and evidence for crustal contamination. Jour. SE Asian Earth Sci. 11, 81-93. 